\title{
UOSLĖS SUTRIKIMAI IR COVID-19
}

\author{
Karolis Liugas $^{2}$, Austėja Kinduryte்2, Ieva Eitavičiūtè $\dot{e}^{1,2}$, \\ Viktorija Kucenko $^{1,2}$, Arnoldas Morozas ${ }^{1,2}$ \\ ${ }^{1}$ Vilniaus universiteto ligonine Santaros klinikos, ${ }^{2}$ Vilniaus universiteto Medicinos fakultetas
}

Raktažodžiai: uoslès funkcijos sutrikimai, uoslès jutimas, anosmija, hiposmija, disgeuzija, COVID-19, SARS-CoV-2, COVID-19 simptomai.

\section{Santrauka}

Uoslès sutrikimas stipriai paveikia pacientų kasdienio gyvenimo kokybę. Šios patologijos priežastys gali būti ìvairios, tačiau pastaraisiais metais pasauliui gyvenant COVID-19 pandemijos sąlygomis, pastebèta, kad nemaža dalis šia infekcija sergančių pacientų skundžiasi uoslès sutrikimu ar visišku jos išnykimu. Tyrimo tikslas - apžvelgti uoslès sutrikimų, atsirandančių sergant COVID-19, epidemiologiją, patofiziologiją, diagnostiką, gydymą bei prognozę.

Išplitęs organizme SARS-CoV-2 užkratas paveikia uodžiamojo epitelio ląsteles ir, turima duomenų, jog pažeidžia uodžiamajij stormenị. Uoslès sutrikimo diagnostikai gali būti naudojami ịvairūs objektyvūs ir subjektyvūs testai. Uoslès sutrikimą, pasireiškusį sergančiajam COVID-19 infekcija, reikia diferencijuoti su nosies ir prienosinių ančių, potrauminiu bei neurodegeneraciniu uoslès pažeidimais. Tikètina, jog bendrosios povirusinių uoslès sutrikimų gydymo metodikos yra naudingos ir tinkamos COVID-19 sukelto uoslès sutrikimo gydymui: aromaterapija, natrio citratas, vietiškai nosyje naudojamas A vitaminas bei teofilinas, sisteminės omega-3 polinesočiosios riebalų rūgštys. Dažniausiai uoslės sutrikimai visiškai atsikuria per kelias savaites, tačiau retais atvejais gali užtrukti iki poros mènesių po pasveikimo.

\section{Ivadas}

Viena iš pagrindinių nosies ir prienosinių ančių funkciju yra uoslè. Šis labai diferencijuotas jutimas padeda nustatyti maisto ir gérimų skonį, orientuotis aplinkoje, atpažinti pavojingas situacijas, pavyzdžiui gaisrą, dujų nuotėki ar sugedusi maistą. Uoslè gali sutrikti po ịvairių invazinių otorinolaringologinių procedūrų, kvapo pojūčio pokyčiai gali būti ankstyvas įvairių ligų požymis, o šio jausmo sutrikimas stipriai paveikia pacientų kasdienio gyvenimo kokybę [1]. Galima išskirti tris pagrindines šios patologijos priežasčiu grupes: 1) apsunkintas kvapo daleliu judèjimas dèl nosies obstrukcijos (sergant lètiniu sinusitu, nosies polipoze, esant perteklinei gleivių gamybai, 2) uodžiamojo nervo pažeidimas centrinëje nervų sistemoje (CNS) (augliai ar šalia esančios anatominès struktūros, kurios spaudžia uodžiamojo nervo laidą), 3) sensorinio epitelio pakenkimas (virusų, toksinų, vaistų poveikis). Vienas iš virusų, kuris gali sukelti kvapo pojūčių sutrikimą ar anosmiją (visišką uoslès išnykimą), yra SARS-CoV-2 (COVID-19) [2]. Iki 2021 metų vasario mènesio pasaulyje buvo patvirtinti daugiau nei 107 milijonai COVID-19 ligos atvejų [3], todèl tikètina, jog daugeliui gydytojų jau teko susidurti su šia infekcija darbo praktikoje. Pandemijos pradžioje buvo pastebèta, kad nemaža dalis COVID-19 pacientų skundžiasi uoslès sutrikimu ar visišku jos išnykimu, vèliau mokslininkai naujai atsiradusi uoslès sutrikimą įtraukè ị COVID-19 ligos simptomų sąrašą kartu su kosuliu, dusuliu, karščiavimu, šaltkreečiu, raumenų ir gerklès skausmais [2]. Verta paminèti, jog uoslès sutrikimas neretai yra vienas iš specifinių požymių sergant koronavirusine infekcija, padedantis diferencijuoti susirgimą, ypač tais atvejais, kai kiti ligos simptomai yra nežymūs [4]. Net iki 85,6 proc. užsikrètusiujų COVID-19 pasireiškia ịvairaus laipsnio uoslès sutrikimai ar anosmija, o kai kuriems pacientams šis pojūtis išlieka sutrikęs net ir praejjus keliems mėnesiams po pasveikimo [5].

Tyrimo tikslas - apžvelgti uoslès sutrikimų, atsirandančių sergant COVID-19, epidemiologiją, patofiziologiją, diagnostiką, gydymą bei prognozę.

\section{Tyrimo medžiaga ir metodai}

Literatūros paieška atlikta Medscape, PubMed, UpToDate medicininèse duomenų bazėse bei specializuotoje informacijos paieškos sistemoje Google Scholar. Detalesnei analizei atrinkti straipsniai, paskelbti nuo 2002 m. iki 2021 m. Didžioji dalis straipsnių publikuoti pastaraisiais metais dèl didelio mokslo bendruomenès ir visuomenès susidomėjimo COVID-19 pandemija. Straipsniai atrinkti atsižvelgiant ị viso teksto prieinamumą, spausdinimo laiką ir turinị - nagrinèti straipsniai apie uoslès sistemos anatomiją, uoslès sutrikimus, susijusius su 
virusinemis infekcijomis, COVID-19 ligos simptomus, eigą ir sąsajas su kvapo pojūčio pokyčiais bei gydymo galimybes. Atsižvelgta į patologijos aktualumą bei situaciją pasaulyje.

\section{Tyrimo rezultatai ir diskusija}

Uoslès anatomija ir fiziologija. Uoslè yra vienas iš primityviausių ir pirmykščių pojūčių, o uoslès receptorius koduojantys genai sudaro didžiausią genų šeimą (net iki $5 \%$ viso žmogaus genomo) [6]. Nors uoslinès srities (lot. regio olfactoria) plotas, esantis nosies skliaute, yra santykinai mažas, tačiau receptorinių ląstelių koncentracija čia didelè, o uodžiamasis epitelis yra beveik dvigubai storesnis nei aplink esantis kvèpuojamasis. Uoslinį epitelį sudaro 4 rūšių ląstelès: liaukinès, pamatinès, atraminès ir receptorinès. Dèl pamatinių ląstelių kas 30-60 dienų vyksta epitelio regeneracija - tai vienintelè vieta suaugusio žmogaus nervų sistemoje, kur mažiau diferencijuotos kamieninès ląstelès pakeičia neuronus [7]. Atraminès ląstelès turi mikroplaukelius ir gelsvos spalvos pigmento, todèl gleiviné šioje vietoje yra gelsvai ruda. Receptoriaus ląstelès yra dvipoliniai neuronai, kurių dendritai su uodžiamaisiais mikroplaukeliais baigiasi gleivinès paviršiuje, kur juos dirgina gleivinès klampiame skystyje tirpstančios kvapų molekulès. Uodžiamujų neuronų nemielinizuoti aksonai, susijungdami ị grupes, formuoja apie 20 uoslès nervų, kurie per akytkaulio akytoje plokštelëje esančias skylutes iš nosies ertmès patenka

1 lentelè. Uoslès jutimo sutrikimo, sukelto COVID-19, diagnostika [11].

\section{Paciento ištyrimas:}

- Pilnas otolaringologinis ištyrimas, naudojant endoskopą, norint atmesti nosies obstrukciją ar kitus nosies bei prienosinių ančiu anatominius pakitimus (navikus, uždegimines ligas).

- Pilnas neurologinis ištyrimas, įtariant neurodegeneracinę ar intrakranijinę priežastị.

\section{Chemosensoriniai tyrimai:}

Subjektyvus ištyrimas:

- Uoslès tyrimai, naudojant vaizdo analogijos skalę SNOT- 22 (2 lentelè), arba paciento įsivertinimą.

\section{Objektyvus ištyrimas:}

- Naudoti patikimus ir patvirtintus diagnostinius tyrimus.

- Uoslès tyrimai nustato kvapo slenksti, kvapų identifikaciją ir atskyrimą.

\section{Vaizdo tyrimai:}

- Prienosinių ančių kompiuterinè tomografija, esant nosies ir prienosinių ančių patologijos įtarimui.

- Uodžiamojo nervo laido ir galvos smegenų MRT. Ittariant uodžiamojo stormens ar uoslès vagos intrakranijinę patologiją. i priekinę kaukolès duobę. Joje, po kaktine smegenų skiltimi, yra uodžiamasis stormuo (lot. bulbus olfactorius) - jame pirmasis neuronas persijungia i antraji. Uodžiamajame stormenyje gauta informacija yra filtruojama, vyksta tolesnis jos apdorojimas, formuojami grįžtamieji ryšiai tarp CNS ir uoslès receptoriaus. Nuo stormens išejusių mitralinių neuronų aksonai formuoja laidą (lot. tractus olfactorius), kuris eina ị uoslès centrus smegenyse. Centrai skirstomi i pirminę (priekiniame uoslès branduolyje, migdoliniame kūne, priekinèje akytoje medžiagoje) ir antrinę (pogumburyje, Amono rage, orbitinejje frontalinèje žievèje) uoslès žievę. Pirminèje uoslès žievèje suvokiamas kvapo stiprumas, formuojami prisiminimai, susiję su kvapu, kuriamos asociacijos su emocijomis. Antrinè uoslès žievè atsakinga už sąmoningą kvapo suvokimą, jo išsaugojimą atmintyje ir autonomines reakcijas ị kvapus.

\section{Patofiziologinis pažeidimo mechanizmas ir specifiniai} bruožai. Koronavirusų paviršiuje randamas spyglio baltymas, kuris jungiasi su specifiniais ląstelių receptoriais ir taip padeda virusui patekti ị šeimininko ląsteles. SARS-CoV-2 virusas ne išimtis. Pastarasis infekuoja ląsteles pasinaudodamas angiotenziną I konvertuojančio fermento 2 (AKF2) receptoriais ir ląstelių paviršiaus proteazėmis TMPRSS2 [8]. Kelios studijos teigia, jog nosies kvèpuojamojo epitelio ląstelès pasižymi didesne AKF2 receptorių ir TMPRSS2 genų raiška, nei trachejjoje ar plaučiuose [9], todèl būtent nosies epitelis yra pagrindinis viruso rezervuaras užsikrètus koronavirusu. Uodžiamasis epitelis, kuris reikalingas kvapo pojūčiui, irgi turi šių genų. Nustatyta, jog AKF2 ir TMPRSS2 yra ekspresuojami Baumano liaukose, atraminèse ir pamatinèse, iš kurių vyksta epitelio regeneracija po pažeidimo, uodžiamojo epitelio ląstelèse. Dar viena kvapo pojūčio pokyčiu priežastis - uždegimas. Gleivinès paburkimas blokuoja kvapo dalelių patekimą i uodžiamojo epitelio ląsteles. Ši teigini patvirtina neseniai atliktas tyrimas, kurio metu COVID-19 pacientams, turintiems anosmiją, atlikta kompiuterinè tomografija - didžiajai daliai sergančiujų rastas blokuotas kelias link uoslinès srities [10]. Uždegimo metu stebimas ne tik gleivinès paburkimas, bet ir padidèjusi uždegiminių mediatoriu ir citokinų gamyba. Šios cheminès medžiagos galimai slopina kvapo receptoriaus geno raišką uodžiamuosiuose sensoriniuose neuronuose [11]. Vietinis uždegimas taip pat sutrikdo ịvairias pagalbinių uodžiamojo epitelio ląstelių funkcijas, sutrinka vandens ir jonų mainai, maisto medžiagų patekimas. Kuo stipresnis ir ilgesnis uždegiminis atsakas, tuo didesnè uodžiamojo epitelio pažaida, todèl kai kuriems pacientams poinfekcinis uoslès sutrikimas tęsiasi ilgai.

Kita uoslès fiziologijoje svarbi anatominè vieta - uodžiamasis stormuo - irgi gali būti pažeista koronavirusinès infekcijos: magnetinio rezonanso tyrimų studijos rodo trumpalaikius uodžiamojo stormens pokyčius. Kai kurie korona- 
virusai gali patekti ị centrinę nervų sistemą per akytają plokštelę ir tiesiogiai infekuoti uodžiamojo stormens ląsteles. Kol kas nèra tikslių duomenų, irodančių, jog tai gali padaryti SARS-CoV-2 virusas. Pelių uodžiamojo stormens imunodažymas, ieškant AKF2 baltymo, parodè, jog AKF2 yra ekspresuojamas kraujagyslių pericituose. Šios ląstelès tiesiogiai atsakingos už hematoencefalinị barjerą, vietinio kraujagyslių tonuso palaikymą ir neuroimuninị atsaką [12]. Tai leidžia manyti, jog virusas, patekęs ị pericitus, gali tiesiogiai (dèl perfuzijos pokyčių) arba netiesiogiai (dèl uždegimo) paveikti chemosensorinį suvokimą smegenyse [8]. Bandant išsiaiškinti, ar COVID-19 virusas gali tiesiogiai paveikti CNS neuronus, kyla daug diskusijų, tačiau iš esmès virusas turi galimybę patekti ị smegenis net keliais skirtingais būdais per kraujagysles, nervus, kurie inervuoja infekuotus audinius, ir tiesiogiai per nosį (akytają plokštelę). Tikslesniems įrodymams kol kas trūksta tyrimų.

COVID-19 sukelto uoslès sutrikimo paplitimas ir diagnostika. Manoma, jog uoslès sutrikimo paplitimas yra apie 62-77 proc. sergančiuju [5,17], tačiau tiksli COVID-19 sukelto uoslès sutrikimo epidemiologija kol kas nèra žinoma. Irane atliktos studijos rezultatai parodè, kad 59 iš 60 pacientų, hospitalizuotu dèl šio viruso, buvo ịvairaus laipsnio uoslès pažeidimų, kurie buvo patvirtinti atlikus psichofiziologinius uoslès diagnostinius tyrimus [13]. Uoslès ir (ar) skonio jutimų sutrikimai dažnai pasireiškia net ir esant lengvai ligos eigai [11]. Kitoje studijoje Italijoje net 64 proc. pacientų, sirgusių vidutinio sunkumo COVID-19 forma, rasta uoslès funkcijos sutrikimų [14]. Iki šiol nèra tiksliai žinoma, koks yra uoslès sutrikimo bei COVID-19 infekcijos sunkumo ryšys. Neretai žmonès, persirgę COVID-19, ịvardija ne tik uoslès suprastejimą, bet ir neịprastus pojūčius - jaučia kvapą, kurio nèra.

Uoslès sutrikimas gali būti specifinis šios infekcijos požymis, ypač kai klinika minimali ar jos nèra [15]. Diagnostika grindžiama pilnu paciento ištyrimu, chemosensoriniais bei vaizdiniais tyrimais (1 lentelè). Uoslès sutrikimas, pasireiškęs sergančiajam COVID-19 infekcija, diferencijuojamas su nosies ir prienosinių an- čių, potrauminiu bei neurodegeneraciniu uoslès pažeidimais (3 lentelè).

Gydymo ir terapijos būdai. Jei poinfekcinis uoslès sutrikimas trunka iki 2 savaičiu - gydymo reikalingumas abejotinas, tačiau kai kvapo pojūčio pokyčiai trunka ilgiau - svarstomos gydymo galimybès. Tikètina, jog bendrosios povirusinių uoslès sutrikimų gydymo metodikos yra naudingos ir tinkamos COVID-19 sukelto uoslès sutrikimo gydymui [18]. Pirmiausia kreipiamas dèmesys ị saugumą - pacientams turètų būti paaiškinama uoslès nusilpimo svarba kasdieniame gyvenime, patariama ịsigyti dūmų ir (ar) dujų nuotèkio detektorius, dažniau tikrinti maisto galiojimo datas ant pakuočių, siekiant išvengti nelaimingų atsitikimų ar apsinuodijimų. Vienas iš pagrindinių gydymo metodų - uoslès treniravimas (aromaterapija). Jos metu po 20 sekundžiu uostomi keturi stiprūs kvapai (dažniausiai pasirenkami citrinos, rožių, eukaliptų ir gvazdikèlių kvapai). Treniruotė atliekama 2 kartus per dieną, o minimali efektyvi terapijos trukmė 3 mènesiai. Studijos rodo kliniškai reikšmingą uoslès funkcijos pagerejjimą pacientams, kurie skundžiasi povirusiniu kvapo

2 lentelè. SNOT- 22 skalè [22].

\begin{tabular}{|l|c|c|c|c|c|c|c|}
\hline \multirow{2}{*}{ Požymiai } & \multicolumn{7}{|c|}{ Problemos sunkumas } \\
\cline { 2 - 8 } & $\begin{array}{c}\text { nèra } \\
\text { proble- } \\
\text { mos }\end{array}$ & $\begin{array}{c}\text { labai } \\
\text { lengva }\end{array}$ & $\begin{array}{c}\text { len- } \\
\text { gva }\end{array}$ & $\begin{array}{c}\text { viduti- } \\
\text { nio sun- } \\
\text { kumo }\end{array}$ & sunki & $\begin{array}{c}\text { labai } \\
\text { sunki }\end{array}$ & $\begin{array}{c}5 \text { sun- } \\
\text { kiau- } \\
\text { sios }\end{array}$ \\
\hline $\begin{array}{l}\text { Poreikis išsišnypšti } \\
\text { nosi }\end{array}$ & 0 & 1 & 2 & 3 & 4 & 5 & \\
\hline Nosies užsikimšimas & 0 & 1 & 2 & 3 & 4 & 5 & \\
\hline Čiaudulys & 0 & 1 & 2 & 3 & 4 & 5 & \\
\hline Sloga & 0 & 1 & 2 & 3 & 4 & 5 & \\
\hline Kosulys & 0 & 1 & 2 & 3 & 4 & 5 & \\
\hline Užnosinis tekejimas & 0 & 1 & 2 & 3 & 4 & 5 & \\
\hline $\begin{array}{l}\text { Tirštos gleivės išsky- } \\
\text { ros }\end{array}$ & 0 & 1 & 2 & 3 & 4 & 5 & \\
\hline $\begin{array}{l}\text { Ausies pilnumo jaus- } \\
\text { mas }\end{array}$ & 0 & 1 & 2 & 3 & 4 & 5 & \\
\hline Galvos svaigimas & 0 & 1 & 2 & 3 & 4 & 5 & \\
\hline Ausies skausmas & 0 & 1 & 2 & 3 & 4 & 5 & \\
\hline $\begin{array}{l}\text { Veido skausmas } \\
\text { (spaudimas) }\end{array}$ & 0 & 1 & 2 & 3 & 4 & 5 & \\
\hline $\begin{array}{l}\text { Susilpnėjusi uoslė } \\
\text { (skonis) }\end{array}$ & 0 & 1 & 2 & 3 & 4 & 5 & \\
\hline Nemiga & 0 & 1 & 2 & 3 & 4 & 5 & \\
\hline Prabudimai nakti & 0 & 1 & 2 & 3 & 4 & 5 & \\
\hline Neišsimiegojimas & 0 & 1 & 2 & 3 & 4 & 5 & \\
\hline $\begin{array}{l}\text { Nuovargio jausmas } \\
\text { po miego }\end{array}$ & 0 & 1 & 2 & 3 & 4 & 5 & \\
\hline Nuovargis & 0 & 1 & 2 & 3 & 4 & 5 & \\
\hline $\begin{array}{l}\text { Sumažėjęs } \\
\text { produktyvumas }\end{array}$ & 0 & 1 & 2 & 3 & 4 & 5 & \\
\hline $\begin{array}{l}\text { Suprastejjusi koncen- } \\
\text { tracija }\end{array}$ & 0 & 1 & 2 & 3 & 4 & 5 & \\
\hline Irzlumas & 0 & 1 & 2 & 3 & 4 & 5 & \\
\hline Liūdesys & 1 & 2 & 3 & 4 & 5 & \\
\hline Gejdos jausmas & 0 & 2 & 3 & 4 & 5 & \\
\hline
\end{tabular}


pojūčio sutrikimu po uoslès treniravimo [19]. Atsižvelgiant ị ekonominį aromaterapijos naudingumą ir didelị saugumą, šis gydymo būdas galètų būti skiriamas pacientams, kuriems persirgus COVID-19, žymus uoslès sutrikimas išlieka ilgiau negu 2 savaites. Gliukokortikoidų (GKK) skyrimas mūsų nagrinèjamu atveju nèra patariamas dèl mažo įrodymų kiekio ir galimų šalutinių reiškinių, išskyrus atvejus, kai pacientai, dar prieš susirgdami koronavirusine infekcija, naudojo purškiamus intranazalinius GKK (pavyzdžiui, sergant alerginiu rinitu). Tokiu atveju vaistų naudojimas gali būti tęsiamas. Pastaruoju metu tiriami ir kiti perspektyvūs medikamentai, kurie gali padèti pacientams, turintiems uoslès sutrikimų: natrio citratas (manoma, kad dalyvauja uoslès receptorių veikimo kaskadose), vietiškai nosyje naudojamas A vitaminas (svarbus uodžiamojo aparato neurogenezei), sisteminès omega-3 polinesočiosios riebalų rūgštys (malšina uždegimą ir skatina uoslès receptorių regeneraciją) [20]. A vitaminas ir omega-3 riebalų rūgštys gali būti vartojamos kaip papildoma terapija, kartu taikant uoslès treniravimo pratimus [17]. Keli mažos apimties tyrimai rodo, jog vietiškai nosyje veikiančio teofilino vartojimas irgi galètų būti efektyvus, gydant kvapo pojūčio sutrikimus [21]. Kol kas nei vienas uoslès sutrikimo gydymo metodas nebuvo moksliškai pagrịstas tyrimais su pacientais, persirgusiais COVID-19 infekcija, tačiau manoma, jog mūsų paminèti terapijos metodai būtų naudingi ir tuo atveju.

Prognozè. COVID-19 sukeltas uoslès funkcijos sutrikimas yra grižtamas procesas - pasveikus per tam tikrą laiką visiškai atsikuria. Dažniausiai gydymas nèra indikuotinas, disfunkcija praeina savaime. Uoslès sutrikimai (anosmija ar hiposmija) gali trukti iki 5 dienų, tačiau dažniausiai pacientai visiškai

3 lentelè. Uoslės jutimo sutrikimo, sukelto COVID-19, diferencinè diagnostika [11].

\begin{tabular}{|l|l|}
\hline $\begin{array}{l}\text { COVID-19 su- } \\
\text { keltas }\end{array}$ & $\begin{array}{l}\text { Staigi pradžia. } \\
\text { +/- kiti COVID-19 simptomai. } \\
\text { Laikini sutrikimai. } \\
\text { Pacientai jaunesni, dažniau - moteriškos lyties. }\end{array}$ \\
\hline Sinonazalinis & $\begin{array}{l}\text { Laipsniška pradžia. } \\
\text { Nosies užgulimas, sloga, veido skausmas. } \\
\text { Kintantis sunkumas. } \\
\text { Sezoniškumas. }\end{array}$ \\
\hline Potrauminis & $\begin{array}{l}\text { Staigi pradžia. } \\
\text { Stiprus pažeidimas (anosmija). } \\
\text { Pastovūs simptomai. }\end{array}$ \\
\hline Neurodegene- \\
racinis & $\begin{array}{l}\text { Laipsniška pradžia. } \\
\text { Dažnai nesupranta savo uoslès ar skonio sutri- } \\
\text { kimų. } \\
\text { Sunkumas pastovus. } \\
\text { Dažniau vyresnio amžiaus žmonėms. } \\
\text { Galimi atminties sutrikimai ar neurologinė simp- } \\
\text { tomatika. }\end{array}$ \\
\hline
\end{tabular}

atgauna šiuos jutimus per kelias savaites ar 30 dienų laikotarpyje nuo simptomų pasireiškimo pradžios [16,5]. Retesniais atvejais uoslès jutimas atsigauna tik po kelių mėnesių [5]. Nustatyta, jog COVID-19 sukelto laikino uoslès pažeidimo prognozè neigiamai asocijuota su vyresniu amžiumi, o geresnès prognozès stebimos moteriškos lyties pacientams [5].

\section{Išvados}

1. Naujai atsiradęs uoslès sutrikimas yra vienas iš COVID-19 ligos simptomu, pasireiškiantis kartu su kosuliu, dusuliu, karščiavimu, šaltkrečiu, raumenų ir gerklès skausmais.

2. SARS-CoV-2 infekuoja uodžiamojo epitelio ląsteles, pasinaudodamas angiotenziną I konvertuojančio fermento 2 (AKF2) receptoriais ir ląstelių paviršiaus proteazèmis TMPRSS2.

3. Magnetinio rezonanso tyrimų studijos rodo trumpalaikius uodžiamojo stormens pokyčius, tačiau kol kas nèra tikslių duomenų, įrodančių, jog tai tiesiogiai gali padaryti SARS-CoV-2 virusas.

4. Bendrosios povirusinių uoslės sutrikimų gydymo metodikos gali būti praktiškai taikomos ir COVID-19 sukelto uoslès sutrikimo gydymui.

5. Uoslès treniravimas (aromaterapija) turètų būti rekomenduojamas tiems pacientams, kuriems persirgus COVID-19 žymus uoslès sutrikimas išlieka ilgiau negu 2 savaites.

6. Manoma, jog COVID-19 sukelto uoslès sutrikimo paplitimas varijuoja nuo 62 iki 77 proc. sergančiujų, tačiau tiksli epidemiologija nèra tiksliai žinoma.

7. Uoslès sutrikimas gali būti šios infekcijosžymuo, ypač pacientams su minimaliai išreikšta klinika ar jos nesant.

8. COVID sukeltos uoslès disfunkcijos gydymui galima rekomenduoti natrio citratą, A vitaminą vietiškai ị nosị, bei sistemines omega-3 polinesočiąsias riebalų rūgštis.

9. Dažniausiai uoslés sutrikimai visiškai atsikuria savaime per kelias savaites nuo simptomų pradžios.

\section{Literatūra}

1. Ballenger WL, Snow JB, Wackym PA. Otorhinolaryngology: head and neck surgery. Shelton, Conn.: BC Decker; 2009.

2. Centers for Disease Control and Prevention. Coronavirus disease 2019 (COVID-19) - symptoms. CDC 2020.

3. World Health Organization. WHO coronavirus disease (COVID-19) dashboard. https //covid19.who.int/

4. Desai M, oppenheimer j. the importance of considering olfactory dysfunction during the COVID-19 pandemic and in clinical practice. J Allergy Clin Immunol Pract 2021;9(1):7-12. https://doi.org/10.1016/j.jaip.2020.10.036

5. Speth MM, Singer-Cornelius T, Oberle M, Gengler I, Brockmeier SJ, Sedaghat AR. Olfactory dysfunction and sinonasal 
symptomatology in COVID-19: prevalence, severity, timing, and associated characteristics. Otolaryngol Head Neck Surg 2020;163(1):114-120.

https://doi.org/10.1177/0194599820929185

6. Som PM, Lawson W, Fatterpekar GM, et al. Embryology, anatomy, physiology, and imaging of the sinonasal cavities. Book Head and Neck Imaging chapter 2, 2011:99-166. Clinical Key. https://www.clinicalkey.com/\#!/content/book/3-s2.0-B978032 3053556000021 ?scrollTo $=\% 23 \mathrm{~h} 10000804$

7. Olfactory system anatomy: overview, olfactory epithelium, olfactory nerve and the cribriform plate. 2021.

8. Hopkins C, Alanin M, Philpott C, Harries P, Whitcroft K, Qureishi A, et al. Management of new onset loss of sense of smell during the COVID-19 pandemic - BRS consensus guidelines. Clin Otolaryngol 2020. https://doi.org/10.22541/au.159015263.38072348

9. Whitcroft KL, Hummel T. Clinical diagnosis and current management strategies for olfactory dysfunction: a review. JAMA Otolaryngol Neck Surg 2019;145(9):846-53.

https://doi.org/10.1001/jamaoto.2019.1728

10. Yan CH, Rathor A, Krook K, Ma Y, Rotella MR, Dodd RL, ir kt. Effect of Omega-3 supplementation in patients with smell dysfunction following endoscopic sellar and parasellar tumor resection: a multicenter prospective randomized controlled trial. Neurosurgery. 2020;87(2):E91-8.

https://doi.org/10.1093/neuros/nyz559

11. Whitcroft KL, Hummel T. Olfactory dysfunction in COVID-19: diagnosis and management. JAMA 2020;323(24):2512. https://doi.org/10.1001/jama.2020.8391

12. Henkin RI, Schultz M, Minnick-Poppe L. Intranasal theophylline treatment of hyposmia and hypogeusia: a pilot study. Arch Otolaryngol Head Neck Surg. 2012;138(11):1064-70. https://doi.org/10.1001/2013.jamaoto.342

13. Moein ST, Hashemian SM, Mansourafshar B, Khorram-Tousi A, Tabarsi P, Doty RL. Smell dysfunction: a biomarker for COVID-19. Int Forum Allergy Rhinol 2020;10(8):944-50. https://doi.org/10.1002/alr.22587

14. Boscolo-Rizzo P, Borsetto D, Fabbris C, Spinato G, Frezza D, Menegaldo A, et al. Evolution of altered sense of smell or taste in patients with mildly symptomatic COVID-19. JAMA Otolaryngol Neck Surg 2020;146(8):729.

https://doi.org/10.1001/jamaoto.2020.1379

15. Young T, Blustein J, Finn L, Palta M. Sleep-disordered breathing and motor vehicle accidents in a population-based sample of employed adults. Sleep 1997;20(8):608-13.

https://doi.org/10.1093/sleep/20.8.608

16. D'Ascanio L, Pandolfini M, Cingolani C, Latini G, Gradoni P, Capalbo M, ir kt. Olfactory dysfunction in COVID-19 patients: prevalence and prognosis for recovering sense of smell. Otolaryngol Head Neck Surg 2021;164(1):82-6. https://doi.org/10.1177/0194599820943530

17. Rodriguez S, Cao L, Rickenbacher GT, Benz EG, Magdamo $\mathrm{C}$, Gomez LR, et al. Innate immune signaling in the olfactory epithelium reduces odorant receptor levels: modeling transient smell loss in COVID-19 patients. medRxiv 2020.

https://doi.org/10.1101/2020.06.14.20131128

18. Cooper KW, Brann DH, Farruggia MC, Bhutani S, Pellegrino R, Tsukahara T, et al. COVID-19 and the chemical senses: supporting players take center stage. Neuron 2020;107(2):219-33. https://doi.org/10.1016/j.neuron.2020.06.032

19. Hou YJ, Chiba S, Halfmann P, Ehre C, Kuroda M, Dinnon $\mathrm{KH}$, et al. SARS-CoV-2 D614G variant exhibits efficient replication ex vivo and transmission in vivo. Science 2020;370(6523):1464-8.

https://doi.org/10.1126/science.abe8499

20. Eliezer M, Hautefort C, Hamel A-L, Verillaud B, Herman P, Houdart E, ir kt. Sudden and complete olfactory loss of function as a possible symptom of COVID-19. JAMA Otolaryngol Neck Surg 2020;146(7):674.

https://doi.org/10.1001/jamaoto.2020.0832

21. Armulik A, Genové G, Betsholtz C. Pericytes: developmental, physiological, and pathological perspectives, problems, and promises. ScienceDirect 2011;21(2):193-215.

https://doi.org/10.1016/j.devcel.2011.07.001

22. Asiri M, Alokby G. Validation and cross-cultural adaptation of the sinonasal outcome test (SNOT)-22 for the Arabian patient population. Cureus 2019;11(4): e4447.

https://doi.org/10.7759/cureus.4447

\section{OLFACTORY DYSFUNCTION IN COVID-19: LITERATURE REVIEW}

\section{K. Liugas, A. Kindurytė, I. Eitavičiūtė,} V. Kucenko, A. Morozas

Keywords: olfactory dysfunction, olfaction, anosmia, hyposmia, dysgeusia, COVID-19, SARS-CoV-2, COVID-19 symptoms.

Summary

Olfactory dysfunction has a significant role in patients' dayto-day life. This pathology may be triggered by various causes. Although, the emergence of a worldwide pandemic due to coronavirus disease 2019 (COVID-19) and frequent reports of smell loss in COVID-19 infected patients have brought new attention to this very important sense. There is evidence that this virus may affect nervous system (bulbus olfactorius) and olfactory epithelium. Olfactory dysfunction diagnostics should include patient examination, chemosensory testing and imaging, if needed. Treatment of persistent COVID-10 smell dysfunction consists of safety counseling, olfactory training (aromatherapy) and adjuvant medication. COVID-19 does not seem to cause permanent injury to olfactory function because complete recovery occurs mostly after two weeks in some severe cases after a couple of months.

The aim of this article is to draw attention and review epidemiology, pathophysiology, diagnosis, treatment, and prognosis of an olfactory disorder associated with COVID-19.

Working methods used - searching for relevant literature in $\mathrm{Pu}$ bMed, Medscape, Cochrane Library, UpToDate medical databases, and Google Scholar, a specialized search engine.

Correspondence to: kinduryte.austeja@gmail.com

Gauta 2021-03-24 